\title{
Religious and spiritual support in the conception of nurses and families of critical patients: a cross-sectional study*
}

\author{
Suporte religioso e espiritual na concepção de enfermeiros e familiares de \\ pacientes críticos: estudo transversal \\ Soporte religioso y espiritual en la concepción de enfermeros y familiares de \\ pacientes críticos: estudio transversal
}

How to cite this article:

Santos PM, Rodrigues KS, Pinheiro LA, Santana BS, Ipólito MZ, Magro MCS. Religious and spiritual support in the conception of nurses and families of critical patients: a cross-sectional study. Rev Esc Enferm USP. 2021;55:e20200508. https://doi.org/10.1590/1980-220X-REEUSP-2020-0508

\section{Petherson Mendonça dos Santos ${ }^{1}$ \\ Kirliane de Sousa Rodrigues ${ }^{2}$ \\ Lucas Andrade Pinheiro ${ }^{3}$ \\ D Breno de Sousa Santana ${ }^{4}$ \\ D Michelle Zampieri Ipólito ${ }^{1}$ \\ D Marcia Cristina da Silva Magro ${ }^{1}$}

* Extracted from the Term Paper: "Influência do suporte espiritual/religioso no cenário do paciente crítico para familiares e enfermeiros", Universidade de Brasília, 2020.

${ }^{1}$ Universidade de Brasília, Faculdade de Ceilândia, Brasília, DF, Brazil.

${ }^{2}$ Centro Universitário Euro-Americano, Brasília, DF, Brazil.

${ }^{3}$ Universidade de Brasília, Faculdade de Medicina, Brasília, DF, Brazil.

${ }^{4}$ Universidade de Brasília, Departamento de Enfermagem, Programa de Pós-Graduação em Enfermagem, Brasília, DF, Brazil.

\begin{abstract}
Objective: To assess the religious and spiritual support in critical care according to the conception of patients' family members and nurses. Method: This is a quantitative cross-sectional study conducted with nurses and relatives of patients admitted to intensive care units. Sociodemographic data were collected and a questionnaire on religiosity and spirituality was applied to family members and the Spirituality and Spiritual Care Rating Scale to nurses. The results with $\mathrm{p} \leq 0.05$ were significant. Results: Sample consisted of intensive care nurses $(n=22)$ and family members $(n=61)$. Intensive care nurses stated that they can provide spiritual care $(p=0.03)$. Of the family members, $88.5 \%$ believed that religiosity and spirituality help in coping with difficult times, highlighting prayer as part of care for critically ill patients $(p=0.02)$. Conclusion: Nurses and family members recognized religious/spiritual support as significant to the process of caring for critically ill patients, even though professional qualification is required for greater integration of this support in daily intensive care.
\end{abstract}

\section{DESCRIPTORS}

Intensive Care Units; Family; Spirituality; Humanization of Assistance; Nursing.
Corresponding author:

Breno de Sousa Santana

Campus Universitário Darcy Ribeiro, S/N

70.910-900 - Brasília, DF, Brazil

bresousas@outlook.com
Received: $11 / 17 / 2020$

Approved: 09/03/2021 


\section{INTRODUCTION}

Spiritual needs are recognized as an important component of nursing care and assessment and, as such, can affect patient outcomes. Spiritual care has been interpreted as one of the attributes of nurses, considered multifaceted and having a holistic approach, incorporated into the patients' physical, psychological, and social needs ${ }^{(1)}$.

Spiritual suffering may be present during the patient's stay in the hospital (2) and, in the search for health recovery, specialized technological resources, ambience, and continuous multiprofessional assessment ${ }^{(3)}$ may be necessary, as well as humanizing practices that make up integrality of care $^{(4)}$.

However, balancing technological and humanizing actions comprises the current scenario of progress in the health area and is, therefore, a challenge. The need for continuous monitoring should not be a reason to justify the imbalance, but surely is the fair measure for qualified and safe critical care ${ }^{(5)}$. An international review study highlights that awareness of the need for spiritual care integrated with daily care in the intensive care unit (ICU) can lead to the development of more comprehensive and possibly more effective care strategies for ICU patients and their families ${ }^{(6)}$.

Humanized care includes the participation of the patient and professionals, and technological resources to overcome apparently insurmountable clinical conditions, in which the family shall also be included, given the repercussions of feelings of failure from the hospitalization process of one of its components ${ }^{(7)}$.

The need to reconfigure the health-disease process emerges from critical patient care settings, so as to contemplate not only the biological domain, but also the social and spiritual ones as part of the problems identified in patients ${ }^{(8)}$.

Based on this perspective, spirituality is understood as the human propensity to the search for meaning and purpose in life that transcends what is tangible, which may or may not be expressed through formal religious participation and relationship with others, in nature and in $\operatorname{art}^{(9)}$, and religiosity as the extent of what an individual believes in, follows and practices, somehow influencing the way people try to live their lives and treat others ${ }^{(10)}$.

Religion and spirituality are recognized as components of palliative care practice, but underestimated in other fields, such as that of critical patient care $^{(7)}$. Thus, given the importance of investigating religiosity/spirituality in a critical scenario, considering the multifactorial nature of events that can interfere in this context, it is important to investigate its influence on health recovery, since nurses' and family members' conceptions can be promising for better understanding and directing more effective strategies and mechanisms that can accelerate health recovery and positively contribute to better professional performance.

Another important situation refers to the lack of knowledge about the potential ways through which the availability of religious/spiritual support can improve the recovery of critically ill patients; therefore, understanding whether the functioning and self-management of complex pathological processes improve with the perception and inclusion of these constructs can represent an efficient contribution to the health recovery process ${ }^{(11)}$. In this context, the question is: what is the conception of the nurse and the patient's family about religious and spiritual support in critical care?

Therefore, the religious and spiritual support in critical care was assessed according to the perception of patients' family members and nurses.

\section{METHOD}

\section{Type OF Study}

This is an exploratory and descriptive, cross-sectional quantitative study, based on the guidelines of Strengthening the Reporting of Observational studies in Epidemiology $(\mathrm{STROBE})^{(12)}$.

\section{LOCAL}

The study setting comprised two adult ICUs of medium and high complexity, integrated to two tertiary public hospitals of the Brazilian Public Health System located in the West and Southwest regions of the Federal District, Brazil.

\section{Population and SAmple}

The population consisted of all nurses and family members of patients admitted to the hospitals' ICU. Sampling was non-probabilistic for convenience and consisted of 22 nurses and 61 patients' relatives, comprising 83 participants.

Nursing professionals (care nurses, nursing residents, and nursing managers) working in the intensive care setting for at least 3 months and family members of patients hospitalized for at least 48 hours in the ICU, over 18 years old, and who visited the patient at least once during the ICU stay were included. The patient's family member was considered to be the individual who, during the period of data collection, visited the patient in the hospital at least once and had some degree of kinship with the patient admitted to the unit.

Professionals on vacation or on leave from work and family members expressing any embarrassment with the study proposal and who did not have the profile of emotional adjustment, recognized as a thought or behavior of coping, in an adaptive way, with the momentary emotional experience, as assessed by the psychologist from the Psychology Service of the ICU of both institutions, were excluded ${ }^{(13)}$.

\section{Data Collection}

Data were collected between January and March 2020 by the principal investigator and two health care students after orientation and training. The variables studied were: age, sex, marital status, education, profession (family), degree of kinship of the family member (children, spouse, sibling, mother, uncle), current occupation (family), time and period 
of professional experience (nurse), place of education (nurse), religion (family member and nurse), religiosity/spirituality (family member and nurse).

The approach of nursing professionals to apply the questionnaires was before or after the shift, depending on availability. Regarding family members, an evaluation was initially carried out by the department's psychologist to provide emotional support, as needed. The approach to the family member took place in a private environment (department room) and the responses obtained were recorded in real time by the researcher, both in the moments prior to the visit or even after the visit, according to the family member's preference and availability, considering situations of low literacy, sensory impairment, intellectual impairment.

The nurses' spirituality and spiritual care were assessed using the Spirituality and Spiritual Care Rating Scale $(\mathrm{SSCRS})^{(14)}$, with cross-cultural adaptation and translation into Brazilian Portuguese in 2015(15). The SSCRS has an internal validity described by Cronbach's alpha 0.733 , considered acceptable, and consists of 5 parts (A, B, C, $\mathrm{D}$ and $\mathrm{E}$ ).

From the SSCRS, parts A (consisting of two questions) and B (consisting of five questions) were used, both made up of variables related to sociodemographic and professional data. To answer the study question, 5 questions from part $\mathrm{C}$ were also applied, aimed at the spiritual approach (Qa (I believe that nurses can provide spiritual care by arranging a visit by the hospital chaplain or the patient's own religious leader, if requested), $\mathbf{Q b}$ ( I believe nurses can provide spiritual care by demonstrating kindness, concern, and joy in care), $\mathbf{Q} \mathbf{g}$ (I believe nurses can provide spiritual care by dedicating time to the patient, giving and ensuring support, especially in times of need), Qk (I believe that nurses can provide spiritual care by listening and allowing patients and their families time to discuss and explore their fears, anxieties, and problems), and Qn (I believe nurses can provide spiritual care while respecting privacy, dignity, and patients' religious and cultural beliefs), related to the Spiritual Care factor of the scale), originally consisting of 17 statements with 5-point Likert-type options, with 1 for totally disagree, 5 for totally agree, and the seven questions that verify the participant's (nurse) opinion about spiritual care and its essential characteristics during the provision of holistic care.

To obtain the family members' considerations about meeting the patient's spiritual and religious needs, the researchers themselves, without validation by judges, created a structured questionnaire based on scientific evidence ${ }^{(16,17)}$ due to the lack of a validated scale directed to the religious/ spiritual approach of the critical patient's relative that achieved the objective of this study. The first part of the questionnaire consisted of items on sociodemographic characteristics, as well as eight 5-point Likert-type questions, ranging from 1 , I totally disagree, to 5, I totally agree, about: (Q1) Religious/spiritual support is a source of support for me, my family, and my family member, who is experiencing this disease; (Q2) the visit of a spiritual provider (priest, pastor, mentor, among others), according to my family member's religious beliefs, could bring comfort to me and to my relative; (Q3) the nurses who are taking care of my family member addressed spiritual/religious support for my family member or me during this hospitalization period; (Q4) nurses in this unit provide emotional support, with compassionate presence and empathetic behavior, listening carefully to my fears, pains, anxieties, and dreams, and give me the opportunity to express feelings such as sadness, anger, regret, among others; (Q5) I believe that religiosity/ spirituality helps in coping with difficult times; (Q6) I consider prayer as part of care; (Q7) I believe that the spiritual/religious support approach brings the multidisciplinary team closer to the family; and (Q8) having a place inside the hospital for prayer/spiritual practice (e.g. chapel) brings comfort to me during my family member's hospital stay.

\section{Data Analysis and Treatment}

Descriptive analysis was performed by calculating the mean, standard deviation, median, 25 th and 75 th percentile, relative and absolute frequencies. The Kolmogorov Smirnov test was performed to check sample normality. To assess the associations, the non-parametric Mann-Whitney and Fisher's exact tests were applied, as appropriate. In all cases, a $\mathrm{p}$-value $\leq 0.05$ was considered as a statistical significance criterion.

\section{Ethical Aspects}

The research was approved by the Research Ethics Committee of the School of Ceilândia (CEP/FCE) of the Universidade de Brasília (UnB) on November 7, 2019 through Opinion No. 3.692.147, and also by the Ethics Committee of the Foundation for Teaching and Research in Health Sciences (FEPECS) of the Health Department of the Federal District (SESDF), Opinion No. 3.755.560, of December 10, 2019, in accordance with Resolution No. 466/2012 of the National Health Council. All participants signed the Free and Informed Consent Form.

\section{RESULTS}

A total of 22 nurses participated, 11 from hospital A and 11 from hospital B. Regarding family members, there were 34 (55.7\%) from ICU A and 27 (44.3\%) from ICU B. Most professionals (77.3\%) and family members (60.7\%) were female, being relatively young, with ages between 35 (31-38) and 39 (35-49) years, respectively (Table 1).

The most frequently reported degree of kinship among family members during the visit was child $(n=22 ; 36.1 \%)$ and sibling $(\mathrm{n}=12 ; 19.7 \%)$. Regarding religion, most family members, compared to protestants $(n=21 ; 34.4 \%)$, declared themselves Catholic ( $\mathrm{n}=32 ; 52.5 \%)$, as shown in Table 1 . A minority belonged to other religions $(n=5 ; 8.2 \%)$ or self-declared as areligious $(n=3 ; 4.9 \%)$.

The themes religiosity and spirituality were addressed during the training of more than half of the nurses ( $n=15$; $68.2 \%$ ), with the majority self-declared as Catholic ( $\mathrm{n}=14$; $63.6 \%)$. The spiritual need was recognized in clinical practice 
Table 1 - Distribution of the sample of nurses and family members according to sociodemographic and professional characteristics Brasilia, DF, Brazil, 2020.

\begin{tabular}{|c|c|c|c|c|c|}
\hline \multirow{2}{*}{ Variable } & \multicolumn{2}{|c|}{ Nurses group $(n=22)$} & \multirow{2}{*}{ Variable } & \multicolumn{2}{|c|}{ Family group $(n=61)$} \\
\hline & n (\%) & Median (25-75) & & n (\%) & Median (25-75) \\
\hline Sex & & & Sex & & \\
\hline Female & $17(77.3)$ & - & Female & $37(60.7)$ & - \\
\hline Male & $5(22.7)$ & - & Male & $24(39.3)$ & - \\
\hline Age (years) & - & $35(31-38)$ & Age & - & $39(35-49)$ \\
\hline Position/Function & & & Occupation & & \\
\hline Care nurse & $17(77.3)$ & - & Unemployed & $15(24.6)$ & - \\
\hline Resident nurse & $4(18.2)$ & - & Teacher & $6(9.8)$ & - \\
\hline Chief/Supervisor & $1(4.5)$ & - & Nursing technician & $5(8.2)$ & - \\
\hline Time of experience in the $I C U^{a}$ & - & $7.0(1.8-9.3)$ & Others & $35(57.3)$ & - \\
\hline Length of experience in the profession ${ }^{a}$ & - & $10(6.5-14)$ & Degree of kinship & & \\
\hline Education institution & & & Son & $22(36.1)$ & - \\
\hline Public & $9(40.9)$ & - & Brother & $12(19.7)$ & - \\
\hline Private & $13(59.1)$ & - & Others & $27(44.2)$ & - \\
\hline Acting shift & & & Marital status & & \\
\hline Morning & $2(9.1)$ & - & Single & $15(24.6)$ & - \\
\hline Afternoon & $1(4.5)$ & - & Married and common-law marriage & $42(68.8)$ & - \\
\hline Night & $2(9.1)$ & - & Others & $4(6.6)$ & - \\
\hline Morning, afternoon and night & $7(31.8)$ & - & Level of education & & \\
\hline Afternoon and night & $3(13.6)$ & - & High school diploma & $23(37.7)$ & - \\
\hline Morning and afternoon & $7(31.8)$ & - & Higher education degree & $25(40.9)$ & - \\
\hline Credit hours (hours) & - & $40(20-49)$ & Others & $13(21.3)$ & - \\
\hline
\end{tabular}

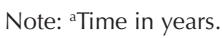

Table 2 - Correlation between the nurses' sex $(\mathrm{n}=22)$ and the questions on the Spirituality and Spiritual Care Rating Scale (SSCRS) Brasilia, DF, Brazil, 2020.

\begin{tabular}{|c|c|c|c|}
\hline \multirow{3}{*}{ Questions } & \multicolumn{2}{|c|}{ Sex } & \multirow{3}{*}{ p-value ${ }^{*}$} \\
\hline & Male $(n=5)$ & Female $(n=17)$ & \\
\hline & Median (25-75) & Median (25-75) & \\
\hline $\begin{array}{l}\text { Qa I believe nurses can provide spiritual care by arranging for a visit from the hospital chaplain } \\
\text { or the patient's own religious leader, if requested. }\end{array}$ & $4(4-5)$ & $4(3-5)$ & 0.9 \\
\hline $\begin{array}{l}\text { Qb I believe nurses can provide spiritual care by showing kindness, concern, and joy in the } \\
\text { care. }\end{array}$ & $4(4-4)$ & $5(4-5)$ & 0.048 \\
\hline $\begin{array}{l}\text { Qg I believe nurses can provide spiritual care by dedicating time to the patient, giving and } \\
\text { ensuring support, especially in times of need. }\end{array}$ & $4(3-4)$ & $5(4-5)$ & 0.1 \\
\hline $\begin{array}{l}\text { Qk I believe nurses can provide spiritual care by listening and allowing patients and their } \\
\text { families time to discuss and explore their fears, anxieties, and problems. }\end{array}$ & $4(4-4)$ & $4(4-5)$ & 0.9 \\
\hline $\begin{array}{l}\text { Qn I believe nurses can provide spiritual care while respecting patients' privacy, dignity, and } \\
\text { religious and cultural beliefs. }\end{array}$ & $4(4-5)$ & $5(4-5)$ & 0.5 \\
\hline
\end{tabular}

Notes: *Mann-Whitney Test.

by nurses as a demand of patients ( $\mathrm{n}=20 ; 90.9 \%)$ and more than half of these professionals declared themselves able to offer this support ( $\mathrm{n}=14 ; 63.6 \%)$. Of the total number of nurses, $72.7 \%$ listed family members, friends, and the religious leader, in addition to the multidisciplinary team, as responsible for providing spiritual care.

The provision of spiritual care was declared important both from the demonstration of kindness, concern, and joy by $13(59.1 \%)$ nurses, and from respect for the patients' privacy, dignity, and religious and cultural beliefs $(n=12$; $54.5 \%)$.

Spiritual care with dedication of time to the patient and provision of support, especially in times of need, was reported as possible by $10(45.5 \%)$ of the nurses, as well as the planning of the visit by the hospital chaplain or religious leader, according to patient's own request. 
In questions related to spiritual care in the SSCRS, the nurses' sex significantly interfered in the ideas about offering spiritual care with kindness, concern, joy $(p=0.048)$ (Table 2).

Of the total number of family members $(n=61)$, $56(91.8 \%)$ fully agreed that prayer represents part of care and $54(88.5 \%)$ that religiosity/spirituality helps in coping with difficult times. More than half $(n=53 ; 86.9 \%)$ of the family members agreed that religious/spiritual support is characterized as a source of support for themselves and their family members in a situation of hospitalization due to illness. It was recognized by most family members ( $n=45$; $73.8 \%$ ) that the visit of a spiritual provider (priest, pastor, mentor, among others), according to their religious belief, can provide some form of comfort (Table 3).

Relatives that are married or in a common-law marriage in the assessment of spiritual and religious support agreed that the visit of a spiritual provider (priest, pastor, mentor, among others) can provide significant comfort for themselves and their hospitalized relative $(p=0.04)$, in addition to recognizing that prayer represents a significant component of care $(p=0.02)$. Moreover, the unemployed family members considered spirituality and religiosity as a help strategy for coping with difficult times $(p=0.04)$. Table 4 showed that the assessment of spiritual support was not influenced by differences in religion among family members $(p>0.05)$.

Table 3 - Description of family members according to the spiritual and religious support questionnaire $(n=61)-B r a s i l i a, D F, B r a z i l, 2020$.

\begin{tabular}{|c|c|c|c|c|c|}
\hline \multirow{2}{*}{ Questions } & TD & D & NS & A & TA \\
\hline & n (\%) & n (\%) & n (\%) & n (\%) & n (\%) \\
\hline $\begin{array}{l}\text { Q1 Religious/spiritual support is a source of support for me, my family, and my } \\
\text { relative, who is experiencing this disease. }\end{array}$ & $0(0.0)$ & $0(0.0)$ & $1(1.6)$ & $7(11.5)$ & $53(86.9)$ \\
\hline $\begin{array}{l}\text { Q2 The visit of a spiritual provider (priest, pastor, mentor, among others) according } \\
\text { to my family member's religious beliefs could bring comfort to me and to my } \\
\text { relative. }\end{array}$ & $2(3.3)$ & $2(3.3)$ & $4(6.6)$ & $8(13.1)$ & $45(73.8)$ \\
\hline $\begin{array}{l}\text { Q3 The nurses who are taking care of my family member have addressed spiritual/ } \\
\text { religious support for my family member or me during this period of hospitalization. }\end{array}$ & $44(72.1)$ & $1(1.6)$ & $11(18.0)$ & $3(4.9)$ & $2(3.3)$ \\
\hline $\begin{array}{l}\text { Q4 The nurses in this unit provide emotional support, with compassionate presence } \\
\text { and empathetic behavior, listening carefully to my fears, pains, anxieties and dreams, } \\
\text { and give me the opportunity to express feelings such as sadness, anger, regret, } \\
\text { among others. }\end{array}$ & $5(8.2)$ & $5(8.2)$ & $13(21.3)$ & $17(27.9)$ & $21(34.4)$ \\
\hline Q5 I believe that religiosity/spirituality helps in facing difficult times. & $1(1.6)$ & $0(0.0)$ & $2(3.3)$ & $4(6.6)$ & $54(88.5)$ \\
\hline $\begin{array}{l}\text { Q7 I believe that the spiritual/religious support approach brings the multidisciplinary } \\
\text { team closer to the family. }\end{array}$ & $2(3.3)$ & $3(4.9)$ & $3(4.9)$ & $14(23.0)$ & 39 (63.9) \\
\hline $\begin{array}{l}\text { Q8 Have a place inside the hospital for prayer/spiritual practice (e.g. chapel) that } \\
\text { brings me comfort during my family member's hospital stay. }\end{array}$ & $5(8.2)$ & $2(3.3)$ & $3(4.9)$ & $5(8.2)$ & $45(75.0)$ \\
\hline
\end{tabular}

Notes: TD - I totally disagree; D - I disagree; NS - not sure; A - I agree; TA - I totally agree.

Table 4 - Correlation of family members' religion in relation to the view on religious/spiritual support - Brasilia, DF, Brazil, 2020.

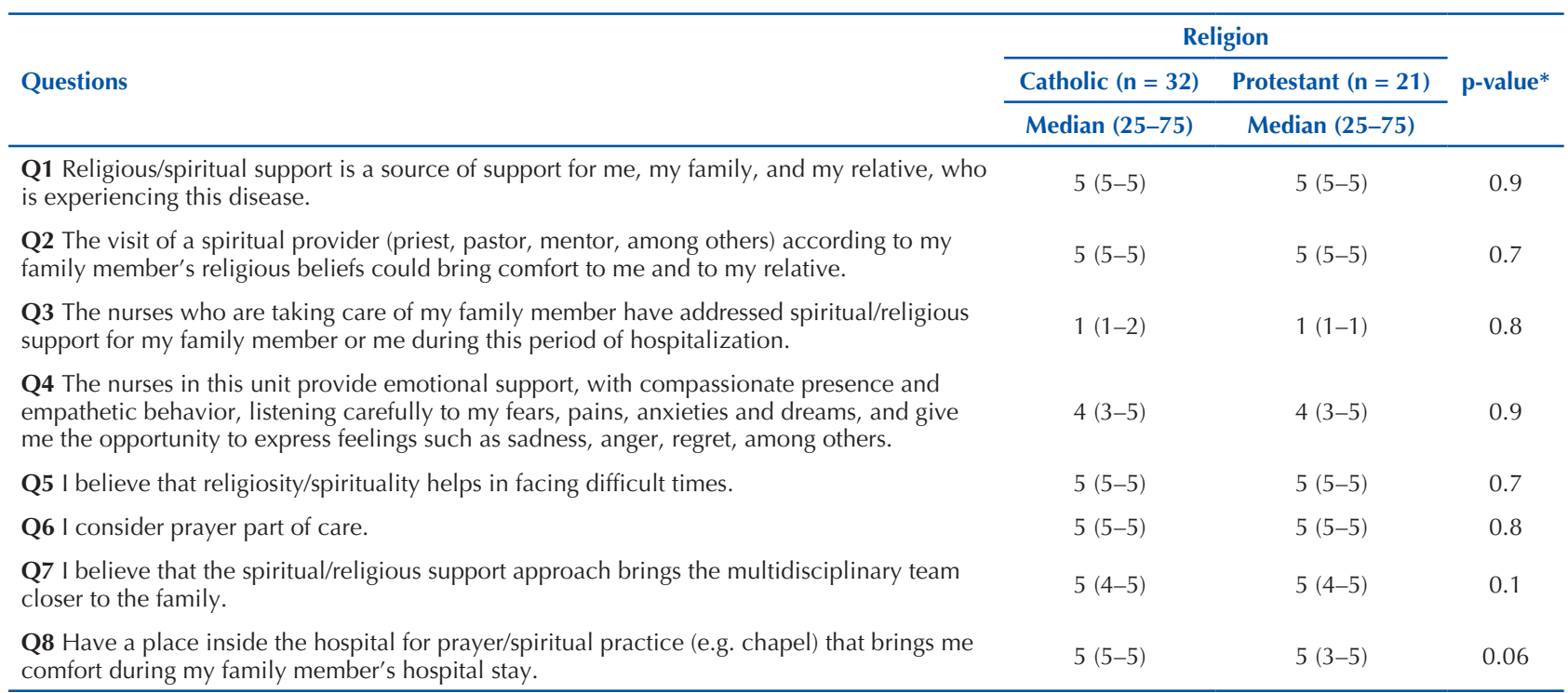

Notes: *Mann-Whitney Test. 


\section{DISCUSSION}

The findings show that, predominantly, nurses with more than five years of experience declare themselves more willing to offer spiritual care $(p=0.048)$, even though they considered time a barrier in this process $(p=0.03)$. The lack of an integrated plan including spiritual care as part of the daily intensive care plan has been revealed as one of the reasons affecting the incorporation of spiritual care in the daily care process ${ }^{(18)}$. The temporal factor should not be underestimated, considering that, in their analysis, nurses recognized it as a potential generator of restrictions on the nurse's ability to monitor spiritual and religious needs $(\mathrm{p}=0.03)$.

Knowledge about spiritual care was recognized as insufficient by nurses; however, they declared that the theme religiosity/spirituality is present during the academic training process. Even so, more than half (63.5\%) of intensive care nurses reported an ability to provide spiritual assistance as a form of care in the critical sphere. It should be noted that the insufficiency of training contents to integrate biological aspects and spiritual support as part of daily care can compromise holistic care, considering that guidelines recommend spiritual support as part of care for critically ill patients ${ }^{(18-19)}$.

The integrated conformation of spiritual assistance by the multidisciplinary team is one of the aspects of care highlighted by the Interdisciplinary Model of Spiritual Care, in which health professionals (nurses, physicians, psychotherapists, occupational therapists) and spiritual caregivers (chaplains) come together ${ }^{(20)}$. In the present study, for example, nurses, regardless of their religious practice, declared the importance of the chaplain in spiritual care $(\mathrm{p}=0.04)$ to promote prayers $(\mathrm{p}=0.02)$ recognized as having an impact on coping, reaching happiness and general well-being ${ }^{(21)}$, and as an interface of the line of care and the family approach ${ }^{(20)}$.

Findings showed that family members, besides recognizing the importance of the professional's availability to provide religious and spiritual backing as a support strategy during the hospitalization of critically ill patients, also highlighted the visit of a spiritual provider as a comfort strategy in the care process. A quasi-experimental study conducted in the United States of America (USA), evaluating the impact of spiritual care provided by the hospital chaplain on adult ICU patients under mechanical ventilation, concluded that spiritual care works as a mitigating measure of anxiety and stress during and after admission to the ICU; thus, in ICU settings, the chaplaincy service has been shown to help family members cope with illness or death ${ }^{(22)}$.

Often, the spiritual and religious perspective has a unique position in people's lives, and it is, therefore, important to recognize this dimension for care planning in the field of those being assisted ${ }^{(23)}$ and as an indicator of the quality of care provided ${ }^{(24)}$. In the present study, most family members agreed that spiritual/religious support is a significant source of support for coping with difficult times $(\mathrm{p}=0.04)$.
A national study, conducted in the state of São Paulo, investigated the level of religious/spiritual comfort and coping of 96 relatives of patients admitted to an adult ICU and 70 admitted to a pediatric ICU and did not show religiosity/spirituality as factors that significantly contribute to family members face critical situations of relatives hospitalized in the ICU ${ }^{(25)}$. However, the findings of the current study revealed that $88.5 \%$ of family members, including those who declared themselves unemployed $(p=0.04)$, at least consider spirituality/religiousness as a coping strategy in the face of situations of hospitalization of relatives in a critical care unit. Above all, a review study highlights that the ability to cope translates into emotional well-being and quality of life ${ }^{(26)}$.

Religious orientations, as well as the ways of expressing religious convictions ${ }^{(21)}$, differ among people but, regardless of this, the perception of family members about providing spiritual and religious support in the critical care setting was not significantly influenced by the practice of different types of religion. A study that described how family members and health professionals experience spirituality in intensive care through a program that meets the wishes of the patient, family and professionals, revealed the appreciation of spiritual support actions by the family and also beyond the religious context ${ }^{(27)}$. Certainly, meeting the spiritual needs has proved to be a measure for the patient's coping and recovery ${ }^{(28)}$.

Family spirituality expresses the strengthening of family health, promoting family commitment, improved emotional well-being, development of new healthy behaviors and healing experiences ${ }^{(29)}$. Family members who are married or in a common-law marriage, in the assessment of spiritual and religious support, in the current investigation, agreed that the visit of a spiritual provider can provide significant comfort for themselves and their hospitalized relatives $(p=0.04)$, recognizing prayers as a component of care $(\mathrm{p}=0.02)$.

The findings of this study corroborate the importance of care for this sphere of care in the intensive environment, corresponding to an integral approach to care for critically ill patients, considering the multifactorial nature of conditions present in this setting and, therefore, the need to integrate the care process.

The limitations of the study are related to the scarcity of instruments that specifically assess the conception of spiritual/religious support by the critical patient's family member. The fact that the research was carried out in only two centers limits the generalization of the findings. Moreover, its cross-sectional nature hinders the establishment of causal relationships. The scarcity of national studies addressing the issue in an intensive setting restricted a broader discussion to the Brazilian reality. Not intending to exhaust the theme, it is recognized that further investigations are critical to know the mechanisms by which spiritual/ religious support affects intensive care. On the other hand, the findings highlight the relevance of this area of critical care as an instrument for coping with the health-disease process. 


\section{CONCLUSION}

Nurses and family members recognized religious/ spiritual support as significant to the process of caring for critically ill patients, even though professional qualification is required for greater integration of this support in daily intensive care.

In the assessment of religious and spiritual support, the integration of a spiritual provider into the health team and the inclusion of prayer as part of care were measures for coping with difficult times recognized as significant, both by nurses and family members in the intensive care settings.

Notably, the religious/spiritual support for the patient and his/her family nucleus in the care of critically ill patients expresses a transforming role and understanding of the value of the critically ill human being for the professional, actively including the family in the care process.

\section{RESUMO:}

Objetivo: Avaliar o suporte religioso e espiritual em cuidados críticos na concepção de familiares de pacientes e enfermeiros. Método: Estudo quantitativo transversal realizado com enfermeiros e familiares de pacientes internados na terapia intensiva. Foram coletados dados sociodemográficos e aplicado questionário sobre religiosidade e espiritualidade para os familiares e aos enfermeiros a escala Spirituality and Spiritual Care Rating Scale. Foram significativos os resultados com p $\leq 0,05$. Resultados: Amostra composta de enfermeiros intensivistas $(n=22)$ e familiares $(n=61)$. Os enfermeiros intensivistas declararam que podem oferecer cuidado espiritual $(p=0,03)$. Dos familiares, $88,5 \%$ acreditaram que a religiosidade e a espiritualidade auxiliam no enfrentamento de momentos difíceis, destacando a oração como parte do cuidado na assistência ao paciente crítico $(\mathrm{p}=0,02)$. Conclusão: Enfermeiros e familiares reconheceram o suporte religioso/espiritual como significativo ao processo de cuidar dos pacientes críticos, ainda que para os enfermeiros seja vigente a necessidade de qualificação profissional para maior integração desse suporte no cuidado intensivo diário.

\section{DESCRITORES}

Unidade de Terapia Intensiva; Família; Espiritualidade; Humanização da Assistência; Enfermagem.

\section{RESUMEN}

Objetivo: Evaluar el soporte religioso y espiritual en cuidados críticos en la concepción de familiares de pacientes y enfermeros. Método: Estudio cuantitativo transversal realizado con enfermeros y familiares de pacientes hospitalizados en UCIs. Se recolectaron datos sociodemográficos y se realizó una encuesta sobre religiosidad y espiritualidad a los familiares y los enfermeros a Spirituality and Spiritual Care Rating Scale. Fueron significativos los resultados con $\mathrm{p} \leq 0,05$. Resultados: Muestra compuesta de enfermeros intensivistas $(n=22)$ y familiares $(n=61)$. Los enfermeros intensivistas declararon que pueden ofrecer cuidado espiritual $(p=0,03)$. Entre los familiares, $88,5 \%$ creyeron que la religiosidad y la espiritualidad auxilian en el enfrentamiento de momentos difíciles, destacaron la oración como parte del cuidado en la asistencia al paciente crítico $(p=0,02)$. Conclusión: Enfermeros y familiares reconocieron el soporte religioso/ espiritual como significativo en el proceso de cuidado a los pacientes críticos, aunque a los enfermeros sea vigente la necesidad de calificación profesional para mayor integración de ese soporte en el cuidado intensivo diario.

\section{DESCRIPTORES}

Unidades de Cuidados Intensivos; Familia; Espiritualidad; Humanización de la Atención, Enfermería.

\section{REFERENCES}

1. Badanta B, Rivilla-García E, Lucchetti G, de Diego-Cordero R. The influence of spirituality and religion on critical care nursing: An integrative review. Nurs Crit Care. 2021;1-19. DOI: https://dx.doi.org/10.1111/nicc.12645.

2. Giske T, Cone PH. Discerning the healing path - how nurses assist patient spirituality in diverse health care settings. J Clin Nurs [Internet]. 2015 [cited 2021 Mar 13];24(19-20):2926-35. Available from: https://onlinelibrary.wiley.com/doi/10.1111/jocn.12907.

3. Luiz FF, Caregnato RCA, Costa MR da. Humanization in the Intensive Care: perception of family and healthcare professionals. Rev Bras Enferm. 2017;70(5):1040-7. DOI: https://doi.org/10.1590/0034-7167-2016-0281.

4. Busch IM, Moretti F, Travaini G, Wu AW, Rimondini M. Humanization of Care: Key Elements Identified by Patients, Caregivers, and Healthcare Providers. A Systematic Review. Patient - Patient-Centered Outcomes Res. 2019;12(5):461-74. DOI: https://doi.org/10.1007/ s40271-019-00370-1.

5. Lima AA, Jesus DS de, Silva TL. Densidade tecnológica e o cuidado humanizado em enfermagem: a realidade de dois serviços de saúde. Physis Rev Saúde Coletiva. 2018;28(3):1-15. DOl: https://dx.doi.org/10.1590/S0103-73312018280320.

6. Willemse S, Smeets W, van Leeuwen E, Nielen-Rosier T, Janssen L, Foudraine N. Spiritual care in the intensive care unit: An integrative literature research. J Crit Care. 2020;57:55-78. DOI: https://doi.org/10.1016/j.jcrc.2020.01.026.

7. Nunez ER, Villa G, McFadden R, Palmisciano A, Lanini I, O'Mahony S, et al. Differences in Family Involvement in the Bedside Care of Patients in the ICU Based on Self-Identified Race. Crit Care Explor. 2021;3(3):e0365. DOI: https://dx.doi.org/10.1097/cce.0000000000000365

8. Wilson ME, Beesley S, Grow A, Rubin E, Hopkins RO, Hajizadeh N, et al. Humanizing the intensive care unit. Crit Care. 2019;23(1):32. DOI: https://dx.doi.org/10.1186/s13054-019-2327-7.

9. Pilger C, Macedo JQ de, Zanelatto R, Soares LG, Kusumota L. Perception of nursing team of an intensive care unit about spirituality and religiousness. Ciência, Cuid e Saúde. 2014;13(3):479. DOI: https://dx.doi.org/10.4025/cienccuidsaude.v13i3.19788.

10. Vitorino LM, Lucchetti G, Leão FC, Vallada H, Peres MFP. The association between spirituality and religiousness and mental health. Sci Rep [Internet]. 2018 [cited 2021 Mar 13];8(1):17233. Available from: http://www.nature.com/articles/s41598-018-35380-w.

11. Alsharari A. The needs of family members of patients admitted to the intensive care unit. Patient Prefer Adherence. 2019;13:465-73. DOI: https://dx.doi.org/10.2147/PPA.S197769. 
12. von Elm E, Altman DG, Egger M, Pocock SJ, Gøtzsche PC, Vandenbroucke JP. The Strengthening the Reporting of Observational Studies in Epidemiology (STROBE) Statement: Guidelines for Reporting Observational Studies. Ann Intern Med. 2007; 147(8):573. DOI: https:// dx.doi.org/10.7326/0003-4819-147-8-200710160-00010.

13. Carver CS. Self-regulation of action and affect. In: Baumeister RF, Vohs KD, editors. Handbook of self-regulation: Research, theory, and applications [Internet]. New York: The Guilford Press; 2004 [cited 2021 Mar 13]. Available from: https://psycnet.apa.org/ record/2004-00163-001.

14. McSherry W, Draper P, Kendrick D. The construct validity of a rating scale designed to assess spirituality and spiritual care. Int J Nurs Stud. 2002;39(7):723-34. DOI: https://dx.doi.org/10.1016/S0020-7489(02)00014-7.

15. Vasques RCY. Validação da Spirituality and Spiritual Care Rating Scale para a enfermagem brasileira [Thesis]. São Paulo: Universidade de São Paulo; 2015.

16. Silva MJP da, Araújo MMT, Puggina ACG. Humanização em UTI. In: Padilha KG, Vattimo MFF, Silva SC da, Kimura M, Watanabe M, editors. Enfermagem em UTI: cuidando do paciente crítico. $2^{\text {a }}$ ed. São Paulo: Manole; 2016. p. 1251-2.

17. Neves JL, Schwartz E, Guanilo MEE, Amestoy SC, Mendieta MC, Lise F. Evaluation of the satisfaction of families of patients cared for intensive therapy units: integrative review. Texto Context - Enferm. 2018;27(2):1-12. DOI: http://dx.doi.org/10.1590/0104-070720180001800016.

18. Willemse S, Smeets W, van Leeuwen E, Janssen L, Foudraine N. Spiritual Care in the ICU: Perspectives of Dutch Intensivists, ICU Nurses, and Spiritual Caregivers. J Relig Health. 2018;57(2):583-95. DOl: https://dx.doi.org/10.1007/s10943-017-0457-2.

19. Ho JQ, Nguyen CD, Lopes R, Ezeji-Okoye SC, Kuschner WG. Spiritual Care in the Intensive Care Unit: A Narrative Review. J Intensive Care Med. 2018;33(5):279-87. DOI: https://dx.doi.org/10.1177/0885066617712677.

20. Hefti R, Esperandio MRG. The Interdisciplinary Spiritual Care Model - A holistic Approach to Patient Care. Horizonte. $2016 ; 14(41): 13$. DOI: https://dx.doi.org/10.5752/P.2175-5841.2016v14n41p13.

21. Poloma MM, Pendleton BF. The Effects of Prayer and Prayer Experiences on Measures of General Weil-Being. J Psychol Theol [Internet]. 1991 [cited 2021 Mar 13];19(1):71-83. Available from: http://journals.sagepub.com/doi/10.1177/009164719101900107.

22. Berning JN, Poor AD, Buckley SM, Patel KR, Lederer DJ, Goldstein NE, et al. A Novel Picture Guide to Improve Spiritual Care and Reduce Anxiety in Mechanically Ventilated Adults in the Intensive Care Unit. Ann Am Thorac Soc. 2016;13(8):1333-42. DOI: https://dx.doi. org/10.1513/AnnalsATS.201512-831OC.

23. Oliveira RM, Santos RMM, Yarid SD. Spirituality/religiosity and HumanizaSUS in Family Health Units. Rev Bras em Promoção da Saúde. 2018;31(1):1-8. DOI: https://dx.doi.org/10.5020/18061230.2018.6524.

24. Ramezani M, Ahmadi F, Mohammadi E, Kazemnejad A. Spiritual care in nursing: a concept analysis. Int Nurs Rev. 2014;61(2):211-9. DOI: http://doi.wiley.com/10.1111/inr.12099.

25. Meneguin S, Pollo CF, Benichel CR, Cunha LK, Miot HA. Comfort and religious-spiritual coping of intensive care patients' relatives. Intensive Crit Care Nurs. 2020;58:102805. DOI: https://doi.org/10.1016/j.iccn.2020.102805.

26. Fitchett G. Recent Progress in Chaplaincy-Related Research. J Pastor Care Couns Adv theory Prof Pract through Sch reflective Publ [Internet]. 2017 [cited 2021 Mar 13];71(3):163-75. Available from: http://journals.sagepub.com/doi/10.1177/1542305017724811.

27. Swinton M, Giacomini M, Toledo F, Rose T, Hand-Breckenridge T, Boyle A, et al. Experiences and Expressions of Spirituality at the End of Life in the Intensive Care Unit. Am J Respir Crit Care Med [Internet]. 2017 [cited 2021 Mar 13];195(2):198-204. Available from: http:// www.atsjournals.org/doi/10.1164/rccm.201606-1102OC.

28. Harrad R, Cosentino C, Keasley R, Sulla F. Spiritual care in nursing: an overview of the measures used to assess spiritual care provision and related factors amongst nurses. Acta Biomed. 2019;90(4-S):44-55. DOI: https://dx.doi.org/10.23750/abm.v90i4-S.8300.

29. Kim SS, Kim-Godwin YS, Koenig HG. Family Spirituality and Family Health Among Korean-American Elderly Couples. J Relig Health. 2016;55(2):729-46. DOI: https://dx.doi.org/10.1007/s10943-015-0107-5. 